\title{
Effect of Vitamin E Supplementation and High Stocking Density on the Performance and Stress Parameters of Broilers
}

-Author(s)
Selvam $\mathrm{R}^{\prime}$
Saravanakumar $\mathrm{M}^{\prime}$
Suresh $\mathrm{S}^{\prime}$
Sureshbabu G'
Sasikumar M"
Prashanth D"II
' Animal Health Science, R\&D Centre, Natural
Remedies Private Limited., Bangalore,
Karnataka, India
"Department of Pharmacology and
Toxicology, Natural Remedies Private
Limited., Bangalore, Karnataka, India
III Formulation and Development, R\&D
Centre, Natural Remedies Private Limited.,
Bangalore, Karnataka, India

\section{-Mail Address}

Corresponding author e-mail address Dr Ramasamy Selvam

Head - Animal Health Science

R\&D Centre, Natural Remedies Private Limited, Plot 5B, Veerasandra Industrial Area, Electronic City PO, Hosur Road

Bangalore 560 100, Karnataka, India. Tel: $\quad+918040209896$

Email: selvam@naturalremedy.com

\section{- Keywords}

Broiler performance, high stocking density، oxidative stress, vitamin $\mathrm{E}$.

\section{ABSTRACT}

The present study was carried out to investigate the effect of dietary supplementation with vitamin $\mathrm{E}$ and stocking density on the mortality, body weight gain, feed conversion ratio, European production efficiency factor, heterophi//lymphocyte $(\mathrm{H} / \mathrm{L})$ ratio and liver glutathione $(\mathrm{GSH})$ and malondialdehyde (MDA) levels of broilers. In total, 570 one-dayold Vencobb 400 broiler chickens were randomly assigned to three treatments, with six replicates each. G1 served as normal control and birds were provided a normal floor space $\left(0.0465 \mathrm{~m}^{2} /\right.$ bird from day 1 to 21 and $0.0929 \mathrm{~m}^{2} / \mathrm{bird}$ from day 22 to 42 ) and basal diet containing vitamin $E$ at $70 \mathrm{~g} /$ ton feed $(n=150)$. G2 and $G 3$ birds were subjected to high stocking density $\left(0.0279 \mathrm{~m}^{2} /\right.$ bird from day 1 to 21 and $0.0557 \mathrm{~m}^{2} /$ bird from day 22 to 42). G2 served as the high stocking density (HSD) control, birds were offered a basal diet with no vitamin $E(n=210)$, whereas $\mathrm{G} 3$ birds were fed a basal diet containing vitamin $\mathrm{E}$ at $70 \mathrm{~g} /$ ton feed $(n=210)$. The birds were fed with feed and water ad libitum throughout the study period. The supplementation of vitamin $E$ to the birds subjected to HSD had a positive effect on body weight gain, feed conversion ratio (FCR), European Production Efficiency Factor (EPEF), $\mathrm{H} / \mathrm{L}$ ratio, and liver GSH and MDA levels with those subjected to HSD and not supplemented with vitamin $\mathrm{E}$. The results of the present study indicate that the supplementation of vitamin $E$ at $70 \mathrm{~g} / \mathrm{ton}$ of feed to broilers subjected to HSD could effectively reverse the negative effects of HSD, and improve broiler performance.

\section{INTRODUCTION}

In general, broilers are subjected to various stressors, which include heat stress due to high ambient temperature, nutritional stress due to dietary nutritional imbalance, overcrowding stress due to housing of a high number birds per space unit, handling stress due to various procedures, like vaccination, debeaking, etc. High stocking density (HSD), along with high environmental temperature, may induce oxidative stress in birds as their body temperature and metabolic rate are relatively high when compared to mammals. Poultry can only express their full genetic potential when reared under thermoneutral temperatures (Cassuce et al., 2013).

One of the most frequent stressors in broiler farms is HSD, because the farmers tend to reduce housing and equipment costs by overcrowding the birds, which negatively affects broiler performance and health. Moreover, heat stress activates the hypothalamic- pituitary-adrenal (HPA) axis and increases corticosterone levels of chickens, resulting in reduced feed intake, body weight gain, relative immune organ weight and innate immunity (Quinteiro-Filho et al., 2010). 
Selvam R, Saravanakumar M, Suresh S, Sureshbabu G, Sasikumar M, Prashanth D
Effect of Vitamin E Supplementation and High Stocking Density on the Performance and Stress Parameters of Broilers
There are several expensive methods available to reduce the negative effects of high temperature and high stocking density, but the dietary manipulation is the easiest approach, and has been supported by several research studies (Souza et al. 2011; Khan et al. 2012). In this respect, vitamin E supplementation has been investigated because of the reported benefits in laying hens during heat stress, and reduced body vitamin E levels during heat stress (Sahin et al., 2001). Many studies have reported that the inclusion of vitamin $E$ in broiler diets not only reduces oxidative stress, but also improves the overall performance, as demonstrated by the higher body weight gain and reduced FCR of broilers fed vitamin E (Adebiyi et al., 2011).

In general, stress stimulates the HPA axis and elevates blood glucocorticoid levels (Siegel, 1980), thereby accelerating the metabolic rates and increasing the generation of free radicals, in particular reactive oxygen species (ROS). These ROS may react with cell structures and attack proteins, nucleotides, carbohydrates and lipids within cell, and when the levels of natural antioxidants are not sufficient to quench the excessive ROS levels, this state is denoted as oxidative stress (Hidalgo et al., 1988). Oxidative stress leads to the development of many pathological process (Gutteridge, 1993), and causes oxidative damage in the tissues and propagation of lipid peroxidation of the highly unsaturated fatty acids present in the cellular and subcellular membrane (Burton and Traber, 1990). This in turn induces a downstream cascade of the formation of reactive oxygen species, resulting in hydroxynonenol (relatively transient ROS) and malondialdehyde free radical. Thus, free radicals cause metabolic disorders, cell death, and growth retardation (Okada, 1996).

Vitamin E ( $\alpha$-tocopherol) is a hydrophobic antioxidant that scavenges the free radicals hydroxyl, alkoxyl, peroxyl and superoxide anion through nonenzymatic defense (Amaneh et al., 2015). Vitamin E has been reported to be an excellent biological antioxidant and its administration reduces the physiological response of organisms to stress through enzymatic and non-enzymatic defense mechanisms against free radicals (Dalolio et al., 2015). One of the many approaches proposed to enhance immune response is the supplementation of broiler diets with vitamin $\mathrm{E}$ at the level of $65 \mathrm{mg} / \mathrm{kg}$ Silva et al. (2011).

Vitamin $\mathrm{E}$ is considered a first line of defense against lipid peroxidation, preventing its chain propagation by quenching free radicals (Bjorneboe et al., 1990). It acts on the early stage of lipid peroxidation (McDowell,
1989), and enhances cell membrane stability (Surai, 2003). Therefore, under stressful conditions, additional dietary vitamin $\mathrm{E}$ supplementation is necessary to protect tissues from lipid peroxidation. The performance of pigs was enhanced when the diet was supplemented with vitamin E at the level 100mg/ $\mathrm{kg}$ of feed (Asghar et al., 1991). The supplementation of vitamin $\mathrm{E}$ to Japanese quail diets significantly alleviated heat stress-related performance impairment, suggesting that dietary vitamin E supplementation is necessary under heat stress conditions (Sahin \& Kucuk, 2001). The supplementation of vitamin $E$ to broilers is also an important factor for the health of humans consuming chicken meat (Adebiyi et al., 2011) as it is known to improve meat quality by upregulating the expression of antioxidant enzyme genes in broilers (Niu et al., 2017).

The stress level of broilers can be measured by various means, and the heterophil to lymphocyte ratio $(\mathrm{H} / \mathrm{L}$ ratio) is the most reliable methods (Mashaly et al., 2004). Several studies concluded that $H / L$ ratio is a more reliable indicator of the perceived magnitude of stress than plasma corticosterone values in avian species. Heterophils are important phagocytic cells in avian species. Gross \& Siegel (1983) reported that the $\mathrm{H} / \mathrm{L}$ ratios of $0.2,0.5$ and 0.8 corresponds to low, medium and high degrees of stress in chickens, respectively. Physiological and physical stressors tend to increase the $\mathrm{H} / \mathrm{L}$ ratio (Maxwell et al., 1998).

Malondialdehyde (MDA) is a three-carbon lowmolecular weight aldehyde, and one of the final products of polyunsaturated fatty acids peroxidation in the cells. Blood MDA level is the most frequently used indicators of lipid peroxidation. Jena et al. (2013) demonstrated that broiler breeders supplemented with vitamin $\mathrm{E}$ had significantly lower malondialdehyde (MDA) levels, increased activities of superoxide dismutase (SOD) and catalase (CAT) enzymes, and ferric reducing antioxidant power (FRAP) in erythrocytes. Serum thiobarbituric acid reactive substances (TBARS) and glutathione (GSH) can also be used as a measure of anti-oxidative status in broilers (Vashan et al., 2012).

No studies had been conducted on the effects of the dietary supplementation of vitamin $\mathrm{E}$ at this low dose (70g/ton of feed) of broilers reared at high stocking densities. The aim of the present experiment was to study the effects of dietary vitamin E supplementation (70 $\mathrm{g} / \mathrm{ton}$ of feed) on the mortality rate, body weight gain, feed conversion ratio, European production efficiency factor, $\mathrm{H} / \mathrm{L}$ ratio, and liver GSH and MDA levels of broilers reared at HSD. 
Selvam R, Saravanakumar M, Suresh S, Sureshbabu G, Sasikumar M, Prashanth D
Effect of Vitamin E Supplementation and High Stocking Density on the Performance and Stress Parameters of Broilers

\section{MATERIALS AND METHODS}

\section{Ethical Approval}

The study was conducted by authorized, qualified and trained veterinarians, scientists, and technicians, in compliance with the guidelines of the Institutional Animal Ethics Committee (IAEC) approved by Committee for the Purpose of Control and Supervision of Experiments on Animals (CPCSEA), India. All applicable international, national, and/or institutional guidelines for the care and use of animals were followed. All procedures performed in studies involving animals were in accordance with the ethical standards of the institution or practice at which the studies were conducted (Selvam et al., 2015).

\section{Birds, Experimental Design and Setup}

A total of 570 Vencobb 400 broiler chicks were used in this study. The experiment was conducted in poultry research station (PRS) located in Anniyalam, Tamilnadu for a period of 42 days between October and November 2014.

The chicks were housed in semi-closed house divided into pens with floor space of 2.32 square meters. The approximate size of the individual pen was $1.3 \times 1.8 \times 0.6 \mathrm{~m}$ (length $\mathrm{x}$ width $\mathrm{x}$ height). Each pen was equipped with a brooder, a bell drinker, chick feeder and/or jumbo feeder. The size and floor space of the pen were modified according to number of chicks housed with the help of a PVC sheet. House temperature was maintained at 32 to $34^{\circ} \mathrm{C}$ from day 0 to 7 , and progressively reduced by $2^{\circ} \mathrm{C}$ weekly till week 6 . House relative humidity $(\mathrm{RH})$ was maintained between 40 to $70 \%$ throughout the study period. Lighting was provided 24 hours daily during the first 3 days, 23 hours light and one-hour darkness between day 4 and 7 , and 20 hours light and 4 hours of dark till day 42, according to Selvam et al. (2015). The chicks were vaccinated against Marek's disease immediately after hatching.

Upon arrival, chicks were provided with 4\% sugar-added water for first four hours to replenish the depleted energy and stimulate feed intake. The chlorinated potable drinking water (Innoclean ${ }^{\mathrm{TM}}$, Natural Remedies Pvt Ltd., 1tablet/500 L) and poultry mash feed manufactured by Biogain Feeds India Pvt Ltd., Bangalore (starter feed with 3,000 kcal metabolizable energy/kg and $20 \%$ crude protein from days 1-21, and finisher feed with 3,150 kcal metabolizable energy $/ \mathrm{kg}$ and $18 \%$ crude protein from days 22-42) were provided ad libitum (NRC, 1994). All birds were vaccinated against Newcastle disease (ND; LaSota strain) and infectious bursal disease (IBD) by eye drop on days 5 and 14, respectively (Selvam et al., 2015).

Upon arrival, chicks were individually weighed, tagged with a wing band bearing an identification number, and randomly assigned to the treatments G1, G2 and G3, with six replicates each, according to randomized complete block design (RCBD). Treatment $\mathrm{G} 1$ served as the control treatment: birds were provided $0.046 \mathrm{~m}^{2}$ (days 1-21) and $0.093 \mathrm{~m}^{2}$ (days 22-42) floor space per bird and a basal diet with the inclusion of vitamin $E$ at $70 \mathrm{~g} /$ ton feed $(n=150)$. Birds in treatments G2 were housed at HSD $\left(0.027 \mathrm{~m}^{2}\right.$ from day 1 to 21 and $0.055 \mathrm{~m}^{2}$ per chick from day 22 to 42 ) and fed the basal diet with no vitamin $E$ inclusion $(n=210)$. Birds in treatment G3 were housed at HSD and fed the basal diet with the inclusion of vitamin $E$ at $70 \mathrm{~g} /$ ton feed $(n=210)$.

The optimal dose of vitamin E ( $70 \mathrm{~g} / \mathrm{ton}$ of feed) was selected based on vitamin $E$ dose-optimization study conducted in our lab (unpublished data). The feed ingredients and the nutritional composition of starter and finisher diets are detailed in Table 1.

\section{Experimental Design and Feeding levels}

\begin{tabular}{|l|c|c|c|c|}
\hline Group & Overcrowding Stress & $\begin{array}{c}\text { No. of birds per } \\
\text { replicate }\end{array}$ & $\begin{array}{c}\text { No. of replicates } \\
\text { per treatment }\end{array}$ & $\begin{array}{c}\text { No. of chicks/ } \\
\text { treatment }\end{array}$ \\
\hline $\begin{array}{l}\text { G1 - Control } \\
\text { (Basal diet with } 70 \mathrm{~g} \text { Vitamin E/ton feed) }\end{array}$ & No & 25 & 6 \\
\hline $\begin{array}{l}\text { G2-HSD Control } \\
\text { (HSD + basal diet without Vitamin E) }\end{array}$ & Yes & 35 & 6 \\
\hline $\begin{array}{l}\text { G3-Test Group } \\
\text { (HSD + Basal diet with } 70 \mathrm{~g} \text { Vitamin E/ton feed) }\end{array}$ & Yes & 35 & 210 \\
\hline
\end{tabular}


Selvam R, Saravanakumar M, Suresh S, Sureshbabu G, Sasikumar M, Prashanth D

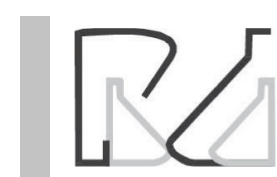

Table 1 - Basal Diet Composition

\begin{tabular}{|c|c|c|}
\hline Ingredients & Starter Feed (g) & Finisher Feed (g) \\
\hline Maize & 645.2 & 658.0 \\
\hline Soya & 255.0 & 228.1 \\
\hline Mustard Oil Cake & 30.0 & 40.0 \\
\hline Meat and Bone Meal & 32.89 & 10.0 \\
\hline Oil & 16.31 & 36.2 \\
\hline Lime Stone Powder & 3.4 & 9.52 \\
\hline Salt & 1.95 & 2.23 \\
\hline Sodium Bicarbonate & 0.75 & 0.75 \\
\hline Methionine Hydroxy Analog & 3.34 & 2.91 \\
\hline Lysine & 3.38 & 3.21 \\
\hline Threonine & 1.05 & 1.0 \\
\hline Vitamin Premix & 0.5 & 0.5 \\
\hline Trace Minerals & 1.0 & 1.0 \\
\hline Curatox-FS ${ }^{\circledR}$ & 1.0 & 1.0 \\
\hline Choline Chloride & 1.5 & 1.5 \\
\hline Biotronic ${ }^{\circledR}$ & 1.0 & 1.0 \\
\hline Zigbir $^{\circledR}$ & 0.5 & 0.5 \\
\hline Coxistac $^{\circledR} 12 \%$ & 0.6 & 0.6 \\
\hline R Sone ${ }^{\circledR} 20 \%$ & 0.25 & 0.25 \\
\hline Ronozyme ${ }^{\circledast} \mathrm{WX}$ & 0.1 & 0.1 \\
\hline Ronozyme ${ }^{\circledR} \mathrm{NP}$ & 0.1 & 0.1 \\
\hline Lincomix ${ }^{\circledast} 20$ & 0.08 & 0.08 \\
\hline Oxifin $^{\circledast}$ & 0.1 & 0.1 \\
\hline Dicalcium Phosphate & - & 1.35 \\
\hline Total & 1000 & 1000 \\
\hline $500 \mathrm{~g}$ of Vitamin Premix cont & & \\
\hline Vitamin A & \multicolumn{2}{|c|}{$12.5 \mathrm{MIU}$} \\
\hline Vitamin $D_{3}$ & \multicolumn{2}{|c|}{$2.5 \mathrm{MIU}$} \\
\hline Vitamin E & \multicolumn{2}{|c|}{ As per experimental design } \\
\hline Vitamin $\mathrm{K}$ & \multicolumn{2}{|c|}{$1.5 \mathrm{~g}$} \\
\hline Vitamin $B_{1}$ & \multicolumn{2}{|c|}{$1.5 \mathrm{~g}$} \\
\hline Vitamin $B_{2}$ & \multicolumn{2}{|c|}{$5 \mathrm{~g}$} \\
\hline Vitamin $\mathrm{B}_{6}$ & \multicolumn{2}{|c|}{$2 \mathrm{~g}$} \\
\hline Vitamin $B_{12}$ & \multicolumn{2}{|c|}{$0.015 \mathrm{~g}$} \\
\hline Niacin & \multicolumn{2}{|c|}{$15 \mathrm{~g}$} \\
\hline Cal. D Pantothenate & \multicolumn{2}{|c|}{$10 \mathrm{~g}$} \\
\hline Folic Acid & \multicolumn{2}{|c|}{$0.5 \mathrm{~g}$} \\
\hline Organic Nutritive Carrier & \multicolumn{2}{|c|}{0.5} \\
\hline
\end{tabular}

\section{Performance parameters}

Birds in individual pens were observed for mortality, three times daily throughout the experimental period. Birds were individually weighed on days 1, 21, and 42 and their body weights were recorded. Feed intake was calculated by subtracting the amount of feed residues from the total amount of feed offered per replicate, and it was measured on days 21 and 42 (Selvam et al., 2015). Feed conversion ratio (FCR) was calculated as feed intake divided by body weight gain. The European Production Efficiency Factor (EPEF) was calculated according to the equation: body weight $(\mathrm{kg})$ $x$ livability $(\%) \times 100 / f e e d$ conversion ratio $x$ age $(d)$ (Selvam et al., 2015).
Effect of Vitamin E Supplementation and High Stocking Density on the Performance and Stress Parameters of Broilers

\section{Sample collection}

Whole blood samples were collected from 12 birds per group (2 birds/replicate) on day 42 in the heparinized centrifuge tubes for $\mathrm{H} / \mathrm{L}$ ratio analysis. The blood smears were prepared using wedge slide technique, air dried, fixed in methanol, and stained with May-Grunwald-Giemsa stain. One hundred leukocyte including granular (heterophil, eosinophil and basophil) and non-granular (lymphocyte and monocyte) cells were counted on duplicates slide per bird, and the $\mathrm{H} / \mathrm{L}$ ratio was calculated using the average counts of these cell types (Onbaşılar et al. 2007).

Birds were sacrificed by cervical exsanguination method after blood collection. Birds were not fasted before the sacrifice. Liver samples were collected from 12 birds per group (2 birds/replicate) on day 42, and stored at $-20^{\circ} \mathrm{C}$ until the analysis of glutathione (GSH) and malondialdehyde (MDA) concentrations. Liver samples were homogenized in an ice-cold Tris- $\mathrm{HCl}$ buffer ( $\mathrm{pH}$ 7.4), and centrifuged at 10,000 $\mathrm{g}$ for 30 minutes at $4{ }^{\circ} \mathrm{C}$. Reduced GSH level was estimated in the liver homogenate by reaction with Ellman's reagent $\{5,5$ - dithiobis-(2-nitrobenzoic acid)\}, as described by Moron et al. (1979), and its final concentration was expressed in $\mu \mathrm{M} / \mathrm{g}$ tissue. Lipid peroxidation levels were evaluated by estimating the amount of MDA produced during peroxidation, according to Ohkawa et al. (1979), and its final concentration was expressed as $\mu \mathrm{M}$ of MDA produced/g of tissue.

\section{Statistical Analysis}

Upon completion of the trial, the raw data were compiled, processed, and expressed as mean \pm SEM. Because a randomized complete block experimental design (RCBD) was applied, the data thus generated was analyzed by one-way analysis of variance (ANOVA) according to Latham et al. (2015), using replicate as a blocking factor to determine if blocking was effective at reducing the random error. In case of significant differences among treatment $(p<0.05)$, means were subjected to Dunnett's multiple comparison test (IBM SPSS Statistics Version 21.0; SPSS Inc., Chicago, IL, USA), according to Latham et al. (2015). Differences were considered statistically significant at $p<0.05$.

\section{RESULTS AND DISCUSSION}

\section{Mortality}

The cumulative mortality percentages observed up to day 42 (at slaughter) were $0.00 \%, 0.95 \%$, and $0.00 \%$ in $\mathrm{G} 1, \mathrm{G} 2$, and $\mathrm{G} 3$, respectively (Table 2). 
Table 2 - Effect of HSD and vitamin E on Performance, Blood and Biochemical Parameters

\begin{tabular}{|c|c|c|c|c|}
\hline \multicolumn{2}{|l|}{ Group } & \multirow{2}{*}{$\begin{array}{c}\text { G1 - Normal Control (Basal } \\
\text { diet with Vitamin E) } \\
0\end{array}$} & \multirow{2}{*}{$\begin{array}{l}\begin{array}{l}\text { G2 - HSD Control (Basal diet } \\
\text { without Vitamin E + HSD) }\end{array} \\
1\end{array}$} & \multirow{2}{*}{$\begin{array}{c}\text { G3 - Test Group } \\
\text { (Basal diet with Vitamin E 70g/ton feed + HSD) } \\
0\end{array}$} \\
\hline \multirow{4}{*}{ Mortality } & Day 1-21 & & & \\
\hline & Day $22-42$ & 0 & 1 & 0 \\
\hline & Total Mortality & 0 & 2 & 0 \\
\hline & Percentage & 0.00 & 0.95 & 0.00 \\
\hline \multirow{3}{*}{ Body weight } & Day 1 & $45.94 \pm 0.24$ & $45.15 \pm 0.28$ & $45.49 \pm 0.22$ \\
\hline & Day 21 & $709.31 \pm 6.18$ & $715.14 \pm 5.46$ & $717.92 \pm 6.02$ \\
\hline & Day 42 & $2294.40 \pm 24.10$ & $* * * 2142.94 \pm 21.50$ & $\$ 2234.29 \pm 21.00$ \\
\hline \multicolumn{2}{|c|}{ Body weight gain (day 42) } & $2248.46 \pm 24.10$ & $* * * 2097.82 \pm 21.50$ & $\$ 2188.80 \pm 20.97$ \\
\hline \multirow{2}{*}{ FCR } & Day 21 & $1.50 \pm 0.02$ & $1.45 \pm 0.02$ & $1.41 \pm 0.01$ \\
\hline & Day 42 & $1.78 \pm 0.02$ & $1.82 \pm 0.02$ & $\$ \$ 1.73 \pm 0.01$ \\
\hline EPEF & & 306.77 & 278.19 & 302.48 \\
\hline \multicolumn{2}{|c|}{ Blood $\mathrm{H} / \mathrm{L}$ ratio } & $0.10 \pm 0.01$ & $* * * 0.20 \pm 0.01$ & $\$ \$ 0.12 \pm 0.01$ \\
\hline \multicolumn{2}{|c|}{ Liver GSH Levels ( $\mu \mathrm{M} / \mathrm{g}$ liver tissue) } & $2.53 \pm 0.08$ & $* * * 1.85 \pm 0.03$ & $\$ \$ 2.23 \pm 0.06$ \\
\hline \multicolumn{2}{|c|}{ Liver MDA Levels ( $\mu \mathrm{M} / \mathrm{g}$ liver tissue) } & $6.13 \pm 0.12$ & $* * 6.74 \pm 0.12$ & $\$ \$ 6.19 \pm 0.14$ \\
\hline
\end{tabular}

Values are expressed as Mean \pm S.E.M; $n=150-210$

${ }^{* *} p<0.01 \&{ }^{* *} p<0.001$ as compared to G1 and $\$ p<0.05, \$ p<0.01 \& \$ \$ p<0.001$ as compared to G2 based on one-way ANOVA followed by Dunnett's Multiple Comparison Test using SPSS

\section{Growth performance}

The growth performance results are shown in the Table 2.

The broilers reared at HSD and fed vitamin E (G3) presented higher BWG on day 42 compared with G2 birds, which were reared at HSD, but were not supplemented with vitamin $\mathrm{E}$. This finding agrees with the authors Hosseini-Mansoub et al. (2010) and Ismail et al. (2014) who found that dietary enrichment with vitamin $\mathrm{E}$ resulted in the better performance when compared to the birds fed with standard diet without vitamin E. Similarly, Sahin \& Kucuk (2001) reported that inclusion of vitamin $E$ in the diet had increased the performance in Japanese quails reared under heat stress $\left(34^{\circ} \mathrm{C}\right)$. Khattak et al. (2012) reported that Vitamin $\mathrm{E}$ supplementation at $300 \mathrm{mg} / \mathrm{kg}$ produced a better performance in broilers under heat stress. However, our results differ with the author Coetzee \& Hoffman (2001) and Nobakht (2012), who reported that there was no difference in body weight gain and FCR between the different dietary levels of vitamin E supplementation. In the present study, HSD reduced the feed consumption of birds that resulted in improvement of FCR without affecting the body weight on day 21 . These results are in line with the findings of the study of Dozier et al. (2006), who observed a similar improvement in growth responses during high stocking density at early stage. The above result could be attributable to augmentation of metabolic heat production process as non-evaporative heat production at HSD, hence the energy required for heat production had diminished; moreover, the chicks at neonatal period (approximately the first two weeks) did not achieve the homeothermic condition and were poorly insulated Whittow (1999). Hence chicks were relatively less active and stayed close to each other leading to energy conservation that might result in better FCR on day 21. The fact observed in the present study that the group reared under normal stocking density having achieved the best growth rate but with the expense of consuming more feed and returned poorer FCR, is due to more liberal space allowance, therefore birds were flightier and active and likely to have expended more energy on unproductive movements Ruan et al. (1990).

On day 42, G2 was found to have gained $151 \mathrm{~g}$ less body weight but with high consumption of feed than $\mathrm{G} 1$ group. Similarly, other studies also reported that there was a significant reduction in body weight attributable to stressors such as increased stocking density or feed restriction in birds Sorensen et al. (2000); Moreira et al. (2004); Thomas et al. (2004); Jang et al. (2009). The suppression of growth performance in HSD could be due to the metabolic heat dissipation, high production of nitrogen and moisture in the litter with limited air circulation, and also high ammonia emissions Yadgari et al. (2006).

However, the inclusion of a diet enriched with vitamin $\mathrm{E}$ (70g/ton of feed) resulted in a $91 \mathrm{~g}$ higher body weight in broilers reared under HSD indicating the overcrowding stress was ameliorated yet the best performance in terms of body weight was detected in those raised under standard conditions. On the other hand, broiler chicks received the vitamin $\mathrm{E}$ 
Selvam R, Saravanakumar M, Suresh S, Sureshbabu G, Sasikumar M, Prashanth D
Effect of Vitamin E Supplementation and High Stocking Density on the Performance and Stress Parameters of Broilers supplementation diets consumed $50 \mathrm{~g}$ lesser amount of feed compared with $\mathrm{G} 1$ that received the basal diet. The above result was consistent with the results of Seier \& Bragg (1993) Niu et al. (2009) and Coetzee \& Hoffman (2001) who reported that dietary vitamin E could improve broiler growth performance. Similarly, Mcllroy et al. (1993) recommended that inclusion of vitamin $\mathrm{E}$ in the diet may be the most beneficial in situation where there is a challenge to the defense system of the host, and could significantly enhance the performance more certainly under such conditions. Correspondingly Kennedy et al. (1992) explored the productivity of 168 broiler chickens fed with vitamin $\mathrm{E}$ supplemented diets either $50 \mathrm{mg} / \mathrm{kg}$ or $180 \mathrm{mg} / \mathrm{kg}$. The authors reported that at the higher level of vitamin $\mathrm{E}$ supplement, productivity was $8.4 \%$ more as a result of improved FCR and body weight gain. Similarly, Sahin \& Kucuk (2001) found that diet with vitamin E produced a higher performance in Japanese quails reared under heat stress $\left(34^{\circ} \mathrm{C}\right)$. The vitamin $\mathrm{E}$ supplementation could reduce the effect of heat stress that would have resulted from the high stocking density.

This result suggests that the vitamin E- inclusion in the diet of broilers subjected to high stocking density could effectively reverse the undesirable effects of overcrowding stress after three weeks of age.

\section{EPEF}

Higher European Production Efficiency Factor (EPEF) was observed in $\mathrm{G} 1$ (306.77) and in G3 (302.48) compared with G2 (278.19), as shown in Table 2.

This result indicates the livability of birds was influenced by stocking density. High stocking density seemed to have stressed the birds, impairing their immunity, and consequently, causing higher mortality. However, mortality rates were not significantly different among treatment groups, as shown in previous reports by Feddes et al. (2002), Thomas et al. (2004), Dozier et al. (2006), Ravindran (2006), who evaluated the effect of HSD on broiler performance. In addition, the lower EPEF observed in $\mathrm{G} 2$ are consistent with the findings of Boltol et al. (1972) and Proudfoot et al. (1979). On the other hand, Roussan et al. (2008) and Samar et al. (2014) reported that the dietary inclusion of vitamin $E$ increased the livability and the body weight of broiler chickens submitted to heat stress.

\section{Physiological stress}

H/L ratio

In our experiment, the result clearly suggests that the vitamin $\mathrm{E}$ supplementation had reduced the $\mathrm{H} / \mathrm{L}$
(0.2 to 0.1 ) ratio equal to the $\mathrm{G} 1$ when compared to G2 (Table 2). This finding corroborates with Altan et al. (2000) and Minka \& Ayo (2008), who found an increase in $\mathrm{H} / \mathrm{L}$ ratios when the birds were subjected to heat and transportation stress. Likewise, Nworgu et al. (2007) and Minka \& Ayo (2008) observed that the values of TLC and $H / L$ ratio were stable when the broilers chickens were treated with anti-oxidant vitamins.

\section{Oxidative stress}

\section{GSH}

Glutathione is a reliable indicator of oxidative stress, and the important function is to protect the cells from the oxidative damage. Rama Rao et al. (2011) reported that supplementing $\alpha$-tocopherol in the diet of broiler chicken had increased the activity of glutathione peroxidase activity in the plasma. Vitamin E supplementation might indirectly increase the GSH concentration by controlling the level of oxygenated radical scavenging systems such as GSH-Px, and depress oxidant enzyme activities through homeostatic compensation Kuan et al. (1990) which agrees with the result of the present study where vitamin $\mathrm{E}$ supplementation significantly improves the liver glutathione concentration in liver of birds under HSD (G3) supplemented with vitamin E when compared to G2 (Table 2). Similarly, the supplementation with vitamin $E(200 \mathrm{mg} / \mathrm{kg})$ in birds during summer months was known to reduce the lipid peroxidation and increase the activity of glutathione when compared to the normal diet Maini et al. (2007).

\section{MDA}

MDA is one of the major final products of lipid peroxidation and based on MDA levels oxidative damage can been determined in the cells. In the present study, the liver MDA concentration in G2 was found to be significantly increased indicating an oxidative stress induced lipid peroxidation. However, vitamin E supplementation ameliorated MDA levels to normal in G3 when compared to G2 which is shown in the Table 2. These results are corroborating with the previous research of Tsai et al. (2008) who reported that maternal vitamin $\mathrm{E}$ supplementation with low doses $(40 \mathrm{mg} / \mathrm{kg}$ ) in hens could supersede the effect of oxidative stress (MDA and ROS) in the neonatal chick brains. Similarly, Sahin et al. (2003) reported that supplementation with vitamin $\mathrm{E}$ had decreased the serum and liver MDA concentration linearly in Japanese quails. Puthpongsiriporn et al. (2001) stated 
Selvam R, Saravanakumar M,

Suresh S, Sureshbabu G,

Sasikumar M, Prashanth D

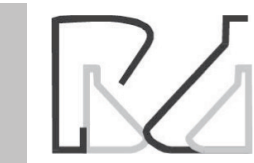

Effect of Vitamin E Supplementation and High Stocking Density on the Performance and Stress Parameters of Broilers that the hens reared under heat stress $\left(32{ }^{\circ} \mathrm{C}\right)$ was found to have increased level of MDA whereas the birds supplemented with vitamin E (65 IU) had the lowest MDA values.

\section{CONCLUSION}

The findings of the present study suggest that the supplementation of vitamin $E$ at $70 \mathrm{~g} /$ ton of feed can overcome the undesirable effects of overcrowding stress and has a positive impact on productive performance, immune responses and anti-oxidant status of broiler chickens.

\section{REFERENCES}

Adebiyi OA, Adu OA, Olumide MD. Performance characteristics and carcass quality of broiler chicks under high stocking density fed vitamin $E$ supplemented diet. Agriculture and Biology Journal of North America 2011;2(8):1160-1165.

Altan O, Altan A, Oguz I, Pabuçcuoglu A, Konyalioglu S. Effects of heat stress on growth, some blood variables and lipid oxidation in broilers exposed to high temperature at an early age. British Poultry Science $2000 ; 41(4): 489-493$

Amaneh MR, Iraj S, Motahareh M. Protective effects of restricted diet and antioxidants on testis tissue in rats fed with high-fat diet. Iranian Biomedical Journal 2015;19(2):96-101.

Asghar A, Gray Jl, Booren AM, Gomaa EA, Abouzied MM, Miller ER, Buckley DJ. Effects of supranutritional dietary vitamin $E$ levels on subcellular deposition of $\alpha$-tocopherol in the muscle and pork quality. Journal of the Science of Food and Agriculture 1991;57(1):31-41

Boltol W, Dewar WA, Jones RM, Thompson R. Effect of stocking density on performance of broiler chicks. British Poultry Science 1972;13:157162.

Burton GW, Traber MG. Vitamin E: antioxidant activity, biokinetics and bioavailability. Annual Review of Nutrition 1990;10:357.

Bjorneboe A, Bjorneboe GE, Drevon CA. Absorption, transport and distribution of vitamin E. The Journal of Nutrition 1990;120(3):233242.

Cassuce DC, Tinôco IF, Baêta FC, Zolnier S, Cecon PR, Vieira MF. Thermal comfort temperature update for broiler chickens up to 21 days of age. Engenharia Agrícola 2013;33(1):28-36.

Coetzee GJM, Hoffman LC. Effect of dietary vitamin E on the performance of broilers and quality of broiler meat during refrigerated and frozen storage. South African Journal of Animal Science 2001;31(3):158-73.

Dalólio FS, Albino LFT, Lima HJD, Silva NJ, Moreira J. Heat stress and vitamin $\mathrm{E}$ in diets for broilers as a mitigating measure. Acta Scientiarum 2015;37(4):419-427

Dozier WA, Thaxton JP, Purswell JL, Olanrewaju HA, Branton S, Roush WB. Stocking density effects on male broilers grown to 1.8 Kilograms of ody weight. Poultry Science 2006;85:344-51.

Feddes JJR, Emmanuel EJ, Zuidhof MJ. Broiler performance, bodyweight variance, feed and water intake and carcass quality at different stocking densities. Poultry Science 2002;81(6):774-779.
Gross WB, Siegel HS. Evaluation of the heterophil/lymphocyte ratio as a measure of stress in chickens. Avian Disease 1983;27(4):972-979.

Gutteridge JMC. Free radicals in disease processes: A compilation of cause and consequence. Free Radical Research Communications 1993;19(3):141-158.

Hidalgo JL, Campmany M, Borras JS, Garvey, Armario A. Metallothionein response to stress in Rats: role in free radical scavenging. American Journal of Physiology 1988;255(4 Pt 1):518-524.

Hosseini-Mansoub N, Chekani-Azar SC, Tehrani AA, Lotfi A, Manesh M. Influence of dietary vitamin $\mathrm{E}$ and zinc on performance, oxidative stability and some blood measures of broiler chickens reared under heat stress (35 $\otimes C$ ). Journal of Agrobiology 2010;27(2):103-110.

Husveth F, Manila HA, Gaal T, Vajdovich P, Balogh N, et al. Effects of saturated and unsaturated fats with vitamin $\mathrm{E}$ supplementation on the antioxidant status of broiler chicken tissues. Acta Veterinaria Hungarica 2000:48(1):69-79.

Ismail FSA, El-Gogary MR, El-Nadi MI. Influence of vitamin E supplementation and stocking density on performance, thyroid status, some blood parameters, immunity and antioxidant status in Broiler Chickens. Asian Journal of Animal and Veterinary Advances 2014;9:702-712.

Jang IS, Kang SY, Ko YH, Moon YS, Sohn SH. Effect of qualitative and quantitative feed restriction on growth performance and immune function in broiler chickens. Asian-Australassian Journal of Animal Sciences 2009;22(3):388-395.

Jena BP, Panda N, Patra RC, Mishra PK, Behura NC, Panigrahi B. Supplementation of vitamin $E$ and $C$ reduces oxidative stress in broiler breeder hens during summer. Food and Nutrition Sciences 2013:4(8):33-37.

Kennedy DG, Rice DA, Bruce DW, Goodall EA, Mcllroy SG. Economic effects of increased vitamin $E$ supplementation of broiler diets on commercial broiler production. British Poultry Science 1992;33:1015-1023.

Khan MW, Privamvada S, Khan SA, Naqshbandi A, Khan S, Yusufi, AN. Protective effect of -3 polyunsaturated fatty acids (PUFAs) on sodium nitroprusside-induced nephrotoxicity and oxidative damage in rat kidney. Human and Experimental Toxicology 2012;31(10):1035-1049.

Khattak FM, Acamovic T, Sparks N, Pasha TN, Joiya MH, Hayat Z, Ali Z. Comparative efficacy of different supplements used to reduce heat stress in broilers. Pakistan Journal of Zoology 2012;44(1):31-41.

Kuan KK, Adnan S, Ramlah H. Effect of increasing stocking density on performance and heterophil/lymphocyte ratios in broilers. Pertanika 1990;13(2):171-175.

Latham RE, Williams M, Smith K, Stringfellow K, Clemente S, Brister R et al. Effect of $\beta$-mannanase inclusion on growth performance, ileal digestible energy, and intestinal viscosity of male broilers fed a reducedenergy diet. Journal of Applied Poultry Research 2016;25(1):40-47.

Maini S, Rastogi SK, Korde JP, Madan AK, Shukla SK. Evaluation of oxidative stress and its amelioration through certain antioxidants in broilers during summer. The Journal of Poultry Science 2007;44(3):339-347.

Mashaly MM, Hendricks GL, Kalama MA, Gehad AE, Abbas AO, Patterson $\mathrm{PH}$. Effect of heat stress on production parameters and immune responses of commercial laying hens. Poultry Science 2004;83(6):889 894

Maxwell MH, Robertson GW. The avian heterophil, leucocyte: a review. World's Poultry Science Journal 1998;54(2):155-178.

Minka NS, Ayo JO. Hematology and behavior of pullets transported by road and administered with ascorbic acid during the hot-dry season. Research in Veterinary Science 2008;85:389-393 
Selvam R, Saravanakumar M,

Suresh S, Sureshbabu G,

Sasikumar M, Prashanth D
Effect of Vitamin E Supplementation and High Stocking Density on the Performance and Stress Parameters of Broilers
Moreira J, Mendes AA, Roca RO, Garcia EA, Naas IA, Garcia RG, et al. Effect of stocking density on performance, carcass yield and meat quality in broilers of different commercial strains. Revista Brasileira de Zootecnia 2004;33:1506-1519.

Mcdowell LR. Comparative aspects to human nutrition. Vitamin in animal and human nutrition. London: Academic Press; 1989. p.207.

Mcllroy SG, Goodall EA, Rice DA, Mcnulty MS, Kennedy DG. Improved performance in commercial flocks with subclinical infectious bursal disease when fed diets containing increased concentrations of vitamin E. Avian Pathology 1993;22(1):81-94.

Moron MS, Depierre JW, Mannervik B. Levels of glutathione, glutathione reductase and glutathione S-transferase activities in rat lung and liver. Biochimica et Biophysica Acta 1979;582(1):67-78

Niu ZY, Liu FZ, Yan QL, Li WC. Effects of different levels of vitamin E on growth performance and immune responses of broilers under heat stress. Poultry Science 2009;88(10):2101-2107.

Niu ZY, Min YN, Liu FZ. Dietary vitamin E improves meat quality and antioxidant capacity in broilers by upregulating the expression of antioxidant enzyme genes. Journal of Applied Animal Research 2017;1-5. Available from: http://www.tandfonline.com/doi/full/10.108 0/09712119.2017.1309321

Nobakht A. The effects of different levels of poultry fat with vitamin $\mathrm{E}$ on performance and carcass traits of broilers. African Journal of Agricultural Research 2012;7(5):1420-1424

Nworgu FC, Ogungbenro SA, Solesi KS. Performance and some blood chemistry indices of broiler chicken served fluted pumpkin (Telfaria occidentalis) leaves extract supplement. American-Eurasian Journal of

Agricultural and Environmental Sciences 2007;2(1):90-98

Ohkawa H, Ohishi N, Yagi K. Assay for lipid peroxidation in animal tissues by thiobarbituric acid reaction. Annals of Biochemistry 1979;95(2):35158.

Okada S. Iron-Induced tissue damage and cancer: The role of reactive oxygen species-free radicals. Pathology International 1996;46(5):311332.

Onbaşılar EE, Erol1 H, Cantekin Z, Kaya Ü. Influence of intermittent lighting on broiler performance, incidence of tibial dyschondroplasia, tonic immobility, some blood parameters and antibody production. Asian-

Australasian Journal of Animal Science 2007;20(4):550-555.

Quinteiro-Filho WM, Ribeiro A, Ferraz-de-Paula V, Pinheiro ML, Sakai M, Sá LRM, et al. Heat stress impairs performance parameters, induces intestinal injury, and decreases macrophage activity in broiler chickens. Poultry Science 2010;89(9):1905-1914.

Proudfoot FG, Hulan HW, Ramey DR. Effect of four stocking densities on broiler carcass grade, the incidence of breast blisters and other performance traits. Poultry Science 1979;58:791-793.

Puthpongsiriporn U, Scheideler SE, Sell JL, Beck MM. Effects of vitamin E and $C$ supplementation on performance, in vitro lymphocyte proliferation and antioxidant status of laying hens during heat stress. Poultry Science 2001;80:1190-1200

Rama Rao SV, Raju MV, Panda AK, Poonam NS, Shyam SG. Effect of dietary $\alpha$-tocopherol concentration on performance and some immune responses in broiler chickens fed on diets containing oils from different sources. British Poultry Science 2011;52:97-105.

Ravindran V, Thomas DV, Thomas DG, Morel PCH. Performance and welfare of broilers as affected by stocking density and zinc bacitracin supplementation. Journal of Animal Science 2006;77(1):110-116.
Roussan DA, Khwaldeh GY, Haddad RR, Shaheen IA, Salameh G, Al Rifai R. Effect of ascorbic acid, acetylsalicylic acid, sodium bicarbonate and potassium chloride supplementation in water on the performance of broiler chickens exposed to heat stress. The Journal of Applied Poultry Research 2008;17(1):141-144.

Ruan KK, Adnan S, Ramlah H. Effect of increasing stocking density on performance and Heterophil/Lymphocyte ratios in broilers. Pertanika 1990;13(2):171-175.

Sahin K, Kucuk O. Effects of vitamin E and selenium on performance, digestion of nutrients, and carcass characteristics of Japanese quails reared under chronic heat stress $\left(34^{\circ} \mathrm{C}\right)$. Journal of Animal physiology and Animal Nutrition 2001;85(11-12):342-348

Sahin K, Sahin N, Onderci M, Gursu M F, Issi M. Vitamin C and E can alleviate negative effects of heat stress in Japanese quails. Food, Agriculture \& Environment 2003;1(2):244-249

Samar ST, Kamel MAH, Ibrahim M, Ibrahim Y. The effect of dietary supplementation of some antioxidants on performance, oxidative stress and blood parameters in broilers under natural summer conditions. The Journal of World's Poultry Research 2014;4(1):10-19.

Seier L, Bragg DB. Influence of dietary vitamin E and antioxidant on the response to dietary selenium by the chick and the biological activity of selenium in feed grain. Journal of Animal Science 1993;53:371-375.

Selvam R, Saravanakumar M, Sureshbabu G. A liquid multivitamin and aminoacid supplement, easygrow ${ }^{\mathrm{TM}}$ on growth performance in vencobb 400 broiler chickens. International Journal of Advanced Scientific and Technical Research 2015:5(2):70-77

Siegel H.S. Physiological stress in birds. Journal of Biological Sciences 1980;30(8):529-534.

Silva I, Ribeiro AML, Canal CW, Vieira MM, Pinheiro CC, Gonçalves T, et al. Effect of vitamin $\mathrm{E}$ levels on the cell-mediated immunity of broilers vaccinated against coccidiosis. Revista Brasileira de Ciência Avícola $2011 ; 3(1): 53-56$

Sorensen P, Su G, Kestin C. Effect of age and stocking density on leg weakness in broiler chickens. Poultry Science 2000;79(6):864-870.

Souza MG, Oliveira RFM, Donzele JL, Assis Maia AP, Balbino EM, Oliveira WP. Use of vitamins $C$ and $E$ on ration for broilers kept in high temperature environment. Revista Brasileira de Zootecnia 2011;40(10):2192-2198.

Surai PF. Natural antioxidants in avian nutrition and reproduction. Nottingham: Nottingham University Press; 2002.

Thomas DG, Ravindran V, Thomas DV, Camden BJ, Cottam YH, Morel $P C$, et al. Influence of stocking density on the performance, carcass characteristics and selected welfare indicators of broiler chickens. New Zealand Veterinary Journal 2004;52(2):76-81.

Tsai HL, Sam KC, Chang, Lin YF, Chang SJ. Beneficial effects of maternal vitamin $E$ supplementation on the antioxidant system of the neonate chick brain. Asian-Australasian Journal of Animal Science 2008;21(2):225-231.

Vashan Hosseini SJ, Golian A, Yaghobfar A, Zarban A, Afzali N, Esmaeilinasab P. Antioxidant status, immune system, blood metabolites and carcass characteristic of broiler chickens fed turmeric rhizome powder under heat stress. African Journal of Biotechnology 2012:11(94):1611816125.

Whittow G. Sturkie's avian physiology. $5^{\text {th }}$ ed New York: Academic Press: 1999.

Yadgari L, Kinereich R, Druyan S, Cahaner A. The Effects of stocking density under hot conditions on growth, meat yield and meat quality of featherless and feathered broilers. World's Poultry Science Journal 2006:62(Suppl):603-604 